\title{
The University Immune System: Overcoming Resistance to Change
}

Ann Gilley, Ferris State University, USA

Marisha Godek, Colorado State University, USA

Jerry W. Gilley, Colorado State University, USA

\begin{abstract}
A university, similar to any other organization, has an immune system that erects a powerful barrier against change. This article discusses the university immune system and what can be done to counteract its negative effects and thereby allow change to occur.
\end{abstract}

Keywords: Change, Organizational Immune System, Resistance to Change

\section{INTRODUCTION}

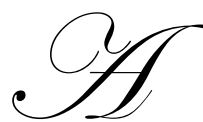

patient fights for his life as his body rejects a critical organ implant. A university struggles to survive amidst a rapidly changing, highly competitive academic landscape. What do these two have in common? Each has an immune system vigorously defending against change. This article explores the impact of the immune system's response to change for individuals and institutions, the similarities between the human body and an institution, and the means by which institutions may effectively engage the immune system and enable change.

Change is constant in institutions; colleges and universities are no exception. The willingness and ability to change enables an institution to enhance efficiency, support research, or remain competitive by attracting students with state-of-the art facilities or degree programs. Conversely, an institution's inability to embrace change often causes operational and financial difficulties that prevent it from being flexible and adaptive to a dynamic business environment.

The inability to cope with change, whether it takes the form of new ideas, initiatives, acquisitions, or other digressions from the status quo, has been the demise of many institutions (Deutschman, 2007). Research indicates that one-third to two-thirds of change efforts don't work or even make the situation worse (Beer, Eisenstat, and Spector, 1990; Muehrcke, 1999). Certain studies have reported success rates of change in some industries being as low as 10\% (Mourier and Smith, 2001).

Why is change so difficult? Universities, like other organizations, possess a powerful immune system that defends the status quo and resists change (Gilley and Gilley, 2003). The university immune system mirrors that of the human body. Understanding the body's response to change heightens our understanding of individual and organizational reactions. We begin with a brief discussion of change and its challenges, explain and compare human and organizational immune systems, and present strategies for universities to work with their immune systems to enable change to successfully occur.

\section{CHANGE}

Most agree that we live in a dynamic, rapidly changing world. Some argue that change is nothing new, while others suggest that change is occurring at an increasingly rapid rate (Collins \& Clark, 2003). This continuous, rapid change significantly impacts the way universities are managed, how they function, and their ability to remain competitive. 


\section{Individuals and Change}

People are inherently resistant to change; thus, avoiding or resisting change is human nature. Reasons for resistance to change are numerous, including one's predisposition toward change, fear of the unknown, disruption of routine, conflict with current culture, breaking routines, fear of failure, lack of reward for change, loss of status, control, power, or security, and so on (Trader-Leigh, 2002).

In his research of adoption of innovations (changes), Rogers (2003) explains the process of change. An innovation is any idea, practice, procedure, or object perceived as new by an individual. Adoption of the new idea or practice is influenced by how the change is communicated via certain channels, over time, among members of a system.

The stages of adoption include awareness of the innovation, interest in the change, trial, the decision to continue or quit, and adoption of the innovation into one's lifestyle. Individuals are categorized on the basis of their general acceptance of change as innovators, early adopters, early majority, late majority, and laggards. Innovators are venturesome, information seekers; early adopters are opinion leaders who are generally respected members of the social group; the early majority are deliberate accepters of change; the late majority are skeptical and occasionally succumb to peer pressure in order to change; and laggards are traditional, steadfast individuals who often attempt to hold on to the past and reject change. Clearly, members of the late majority and laggards are most resistant to change.

Similarly, people may only change when they have the capacity - ability and willingness - to do so (Connor, 1992). Ability involves possessing the necessary skills and knowing how to use them. Willingness implies motivation to apply one's skills and knowledge. When one lacks either ability or willingness, successful adaptation to change is unlikely. Other research suggests that individual resistance is lessened, and successful change stems, from effective leadership, employee involvement, communications, and motivation, among others (Gill, 2003; Sims, 2002; Denning, 2005).

In spite of abundant research, organizational change results have been dismal. Why? Research and practice have ignored the greatest barrier to change and the cause of resistance - the institutional immune system.

\section{THE IMMUNE SYSTEM}

Institutions, like the human body, are systems (Burke 2002). The human body consists of many subsystems (e.g., skeletal, muscular, respiratory, etc.) that must function efficiently and in concert. Similarly, colleges and universities are comprised of multiple layers, departments, and functions that constitute a complex network of interrelated people and processes. The best and healthiest systems are those that are dynamic - capable of recognizing and responding to change in a positive manner. Why then are individuals and institutions so resistant to change? Whether considering the human body or a university, the answer lies within the innate responses of the system to change. A comparison of human and institutional immune systems is next.

\section{Human Immune System}

The immune system is designed to protect the body by identifying and destroying infectious agents that are responsible for disease (e.g., bacteria, viruses), recognizing the body's own cells growing out of control (e.g., cancer cells), and responding to non-biological stimuli such as a sliver (Goldsby, Kindt, and Osborne, 2000b).

A specific cell called the macrophage resides at every portal of entry to the body - the eyes, nose, mucosa, lungs, gastrointestinal tract, and so forth (Auger and Ross, 1992). The circulating form of the macrophage moves throughout the body in search of foreign entities, which can be anything that the body does not recognize as its own "self," such as bacteria, viruses, tumor cells, tissue grafts and the biomaterials used to make surgical implants (Goldsby, et al, 2000a). Macrophages ingest, degrade, or physically separate foreign objects from the rest of the body. This "foreign body response" isolates the material from the body and removes the insult (Anderson, 1993). 
The immune system responds in survival mode, even rejecting tissue and organ implants designed to help prolong or improve one's life.

A local response is characterized by inflammation (swelling, redness, pain), coagulation (clotting), infection, or tumorigenesis (tumors) (Goldsby et al, 2000b). A systemic, or whole body response, includes hypersensitivity, embolization (blockage due to a clot), toxemia (poisons are present in the blood), or metastasis (a system out of control, as with spreading cancers) (Goldsby et al, 2000d).

\section{Problems With the Human Immune System}

When the immune system fails or misjudges a threat the results can be catastrophic, including infection, illness, or death. Misidentification of the body's own self-cells or tissues may allow cancer to spread or may degrade healthy cells, as commonly seen with autoimmune disorders (where the body attacks and destroys itself). Further, the immune system is responsible for organ implant and tissue graft failure when healthy donor tissues are rejected. The body determines that they are foreign or non-self, and proceeds to destroy them (Goldsby, et al, 2000c).

\section{Organizational Immune System}

How is the body comparable to an organization? Human and organizational systems are remarkably similar - both are complex yet delicate collections of interrelated functions and people. An organization's immune system, like the human immune system, protects against change (intrusions) by erecting a powerful barrier. The organizational immune system is comprised of the people, policies, procedures, processes, and culture it creates to prevent change, regardless of the consequences (Gilley, Godek, \& Gilley, 2009).

People, like macrophages, are the gatekeepers of the status quo, fearful of change and the potential consequences of behaving in a different manner. Executives, managers, and employees view policies, procedures, processes, and culture as providing control, continuity, and security, resulting in a comfortable status quo that seems preferable to the uncertainty of risk. Change threatens all of this. Few people possess the desire or ability to deal with uncertainty, choosing instead the known (even if painful) over the unknown.

The organizational immune system's protective, survival mode response is ubiquitous, however, and may ultimately harm the body. The immune system attacks all intruders, with little attention to the overall implications similar to the rejection of new ideas in an institutional setting. Often the individual's response (like the cell's response) is a visceral defensive move with no consideration of the overall well being of the system (the organization).

Just as macrophages engulf (ingest) objects and present them to other components of the immune system for further interrogation (Anderson, 1993), people encounter new ideas and form opinions, which they then present to other employees for acceptance or rejection. In a cellular setting the body responds based on the initial interrogation by the macrophage, in which a threat may be real or simply perceived. Similarly, organizational change may be viewed by employees as a real threat, even when the change is potentially positive.

\section{UNIVERSITY CHALLENGES}

Do universities face the same challenges as other organizations? The same immune system? Our work with colleges and universities reveals that they do. Academic institutions have engaged in multiple changes over the past few years, running the gamut from large-scale, moderate, to small. Common large-scale changes include university-wide systems overhauls and new leadership (President, Provost/VPAA, Dean, etc.); examples of moderate changes included new mid-level managers (Dept Head or Chair), facilities or departmental moves, and new or modified degree programs; examples of small changes included the hiring of new personnel or faculty, tuition increases, and minor procedural or curriculum enhancements. Although change does occur, moderate and large-scale changes involve a great deal of pain in the form of stress, conflict, lowered morale, absenteeism, and employee turnover. Minor changes tend to be more successful and less painful. 


\section{Institutional Barriers to Change}

When asked to identify the greatest institutional barriers to change, the majority of individuals state "people." Other commonly cited barriers include poor (or lack of) leadership, insufficient communications, lack of employee involvement, dysfunctional culture, restrictive policies and procedures, and cumbersome bureaucracy.

\section{Strategies for Overcoming Barriers to Change}

Faculty and staff share the following ideas for overcoming obstacles to change:

- $\quad$ Managers/leaders need to enhance their understanding of change processes and individual reactions

- $\quad$ Make change personal; understand employees' unique needs

- Involve employees in all phases of the change (from idea generation to implementation)

- $\quad$ Communicate frequently and appropriately

- $\quad$ Change should be incremental, not radical

- $\quad$ Reward, don't punish, change efforts

University faculty and staff view change similarly, cite similar barriers, and experience comparable reactions to change as employees in other types of organizations.

\section{HOW CAN UNIVERSITIES SUBDUE THE IMMUNE SYSTEM AND SUCCESSFULLY IMPLEMENT CHANGE?}

The human body is predisposed to reject intrusions, thanks to the diligence of the immune system. Similarly, institutions respond to change without exception. Unlike the human body, many universities and their employees (at all levels, from leadership to front line) fail to even tolerate change. For many, change invokes an instant, defensive response that often recedes only upon defeat of the change via overt or covert methods. How do we prevent rejection and accept desired change? For the body, medical science uses the following strategies, typically via drug therapy:

1. disarm the immune system (stop the chain of events at the macrophage level; halt the attack before it occurs)

2. modify cellular behaviors so that the intrusion (change) can be tolerated

3. conceal the intrusion (change) from the immune system (Goldsby et al, 2000c).

Similarly, universities may also modify individual behaviors, conceal the change, or disarm the immune system when their HR professionals, supervisors, managers, and leaders enhance their own change skills (modify), make change personal (modify, disarm), involve employees in the change initiative (modify, disarm), communicate effectively (disarm), execute change incrementally (conceal), and reward employees' change efforts (modify).

\section{Enhance Change Skills}

Administration and management typically drive change and, thus, should be skilled in change implementation and overcoming resistance. Enhancing management skills in change is essential and should be an on-going priority within institutions given the constant nature of change. Management / leadership training and education are valuable in enhancing understanding of the range of human reactions to change, how to communicate effectively, how to implement and monitor change, and how to reduce resistance and gain commitment.

Some individuals navigate quickly through the change process; others need more time, stall, or vacillate between phases. Understanding human reactions to change, responding appropriately, communication, and involvement are the keys to leading employees through the change and to acceptance. 


\section{Make Change Personal}

Ones approach to change is a unique combination of personality, experiences, values, culture, and more. Natural resistance to change, however, can be lessened by reducing or removing the barriers to change. Given that barriers to change include components of the institutional system itself (e.g., poor leadership, dysfunctional culture, lack of management support, and so forth), it is imperative that strategies for overcoming resistance focus on all levels of the organization.

\section{Involve Employees}

Individuals support what they create; involvement creates psychological ownership of decisions and accountability for their success. Employee involvement and support prove critical to successfully implementing change as those allowed to meaningfully participate in change are more committed to its success (Sims, 2002).

\section{Communicate}

Communication - open, honest, two-way communication - reduces resistance by keeping all stakeholders informed of the change. Effective communication reduces fear of the unknown and promotes the positive aspects of the change. Providing data, answering questions, "selling" the benefits of change, encouraging feedback help people overcome resistance and work through change. Individuals desire information, input, and opportunities to succeed. By valuing individuals' contributions and respecting the energy of dissent, institutions can lead effective change efforts in a dynamic environment.

\section{Execute Change Incrementally}

Incremental change occurs gradually, and takes place within already existing contexts, cultures, value systems, or organizational structure. Individuals are better able to adjust to incremental change, which is perceived as less threatening and easier to integrate into existing processes.

\section{Reward Change Efforts}

An effective compensation and reward strategy recognizes employees for desired performance, such as embracing change, by supporting each step of the institution's change process. Employees respond favorably to celebrating milestones, being rewarded for incremental change, and to managers who create "win-win" situations related to change and innovation (Lussier, 2006). Reward programs should be designed to help organizations achieve specific change outcomes such as creativity and innovation, leadership, teamwork and cooperation, commitment and loyalty, long-term solutions, and learning and applying new skills (Ulrich, Zenger, \& Smallwood, 1999).

\section{CONCLUSION}

Colleges and universities, like the human body, are systems resistant to change. Understanding the human body's response to change on a micro level enables us to better understand and manage resistance in order to successfully execute change on a macro, institutional level.

\section{AUTHOR INFORMATION}

Ann Gilley is an Associate Professor of Management in the College of Business at Ferris State University. She is the author or co-author of numerous articles, books, and book chapters including The Praeger Handbook of Human Resource Management, The Manager as Change Leader, The Performance Challenge, and Organizational Learning, Performance and Change, recipient of the Academy of Human Resource Development Book-of-the Year Award in 2000. Dr. Gilley has more than 20 years of marketing, management, and consulting experience. Her research interests include change, the organizational immune system, and managerial malpractice. 
Marisha L. Godek is a Senior Research Scientist with Covidien Surgical Devices. Dr. Godek's research and publications focus on physiological responses to surgically placed biomaterials. Her research regarding the immune system and collaborations with leading academic and business leaders have yielded relevant correlations between the body and organizations.

Jerry W. Gilley is Professor and Chair of the Organizational Development and Change master's and PhD programs at Colorado State University, and the former President of the Academy of Human Resource Development (AHRD). Dr. Gilley has authored or co-authored numerous books, which include Manager as Coach, Manager as Politician, Strategically Integrated HRD, Principles of Human Resource Development, The Manager as Change Agent, and Organizational Learning, Performance, and Change: An Introduction to Strategic HRD, which was selected the HRD Book of the Year (2000) by the Academy of HRD.

\section{REFERENCES}

1. Anderson, J.M. (1993). Mechanisms of inflammation and infection with implanted devices. Cardiovascular Pathology, 2(3) (Suppl.): 33S-41S.

2. Auger, M. J., and Ross, J. A. (1992) The biology of the macrophage. In C.E. Lewis and J. O'D. McGee (Eds.), The Macrophage (pp. 1-12). Oxford: Oxford University Press.

3. Beer, M., Eisenstat, R. A., and Spector, B. (1990). Why change programs don't produce change. Harvard Business Review, 68(6), 158-166.

4. $\quad$ Burke, W. W. (2002). Organizational change: Theory and practice. Thousand Oaks, CA: Sage Publications.

5. Collins, C. J., \& Clark, K. D. (2003). Strategic human resource practices, top management team social networks, and firm performance: The role of human resource practices in creating organizational competitive advantage. Academy of Management Journal, Vol 46(6), 740-751.

6. $\quad$ Denning, S. (2005). Transformational innovation. Strategy \& Leadership. 33(3), 11-16.

7. Deutschman, A. (2007). Change or die: Three keys to change at work and in life. New York: HarperCollins Publishers.

8. Gill, R. (2003). Change management - or change leadership? Journal of Change Management, 3(4), 307321.

9. Gilley, A., Godek, M., and Gilley, J. W. (2009). The organizational immune system. In Gilley, J.W. Gilley, S. Quatro, and P. Dixon-Krausse, The Praeger Handbook of Human Resource Management. Westport, CT: Praeger Publishing.

10. Goldsby, R. A., Kindt, T. J. and Osborne, B. A. (2000a). Cells and organs of the immune system. In J. Kuby, Immunology (pp. 27-60). New York: W.H. Freeman and Co.

11. Goldsby, R.A., Kindt, T. J., and Osborne, B. A. (2000b). Overview of the immune system. In J. Kuby, Immunology (pp. 3-26). New York: W.H. Freeman and Co.

12. Goldsby, R.A., Kindt, T. J., and Osborne, B. A. (2000c). Transplant immunity. In J. Kuby, Immunology (pp. 517-538). New York: W.H. Freeman and Co.

13. Goldsby, R.A., Kindt, T. J., and Osborne, B. A. (2000d). Cancer and the immune system. In J. Kuby, Immunology (pp. 539-540). New York: W.H. Freeman and Co.

14. Lussier, R. N. (2006). Management fundamentals: Concepts, applications, skill development (3 ed.). Mason, OH: Thomson South-Western.

15. Mourier, P., \& Smith, M. R. (2001). Conquering organizational change: How to succeed where most companies fail. Atlanta, GA: CEP Press.

16. Muehrcke, J. (1999). Meeting the test of time. Nonprofit World, 17(6): 2-3.

17. Rogers, E. M. (2003). Diffusion of innovations $\left(5^{\text {th }}\right.$ ed.). New York: The Free Press.

18. Sims, R. R. (2002). Employee involvement is still the key to successfully managing change. In Sims, S. J, and R. R. Sims (eds.), Changing the way we manage change. Quorum Books: Westport, CT.

19. Trader-Leigh, K. E. (2002). Identifying resistance in managing change. Journal of Institutional Change Management, 15(2), 138-156.

20. Ulrich, D., Zenger, J. \& Smallwood, N. (1999). Results-based leadership: How leaders build the business and improve the bottom line. Boston: Harvard Business School Press. 